\title{
GEOTECHNOLOGY APPLIED TO THE MORPHOLOGICAL ANALYSIS OF ARACATIMIRIM RIVER ESTUARY (TORRÕES - CE)
}

\author{
A.A. Silva ${ }^{1}$ *; T.O. Falcão-Quintela ${ }^{2}$; I.B. Magalhães ${ }^{1}$; L.S. Pinheiro ${ }^{3}$; L.S. Pinheiro ${ }^{2}$ M.L Calijuri $^{1}$ J. C. de Oliveira ${ }^{1}$; J.O. Morais ${ }^{4}$; \\ ${ }^{1}$ Federal University of Viçosa; University campus, Viçosa - MG, Brazil - (arthur.amaral, iara.barbosa, oliveirajc, calijuri)@ufv.br \\ ${ }^{2}$ University of Fortaleza - UNIFOR; Fortaleza - CE, Brazil - (tatifal, ladiane)@unifor.com \\ ${ }^{3}$ Federal University of Ceará - UFC; Fortaleza-CE, Brazil - lidriana.lgco@gmail.com \\ ${ }^{4}$ Ceara State University- UECE; Fortaleza-CE, Brazil - jaderonofre@gmail.com
}

KEY WORDS: Estuary, Geotechnology, Morphological analysis, Coastal environments, Aracatimirim River

\begin{abstract}
:
Estuaries are unstable coastal environments of transitional character between the continent and the ocean that plays an important role in fauna reproduction. In general, these types of coastal features have suffered several environmental impacts due to inadequate forms of use and occupation, which result in significant modifications in the morphology of river mouths. This work aims to apply geotechnologies to study the morphological changes at the mouth of Aracatimirim River, Ceará, Brazil, contributing with useful information on the monitoring and environmental management of tropical coastal estuaries. The methodology was divided into three stages: recognition of the study area; field activity and data processing and integration. The Aracatimirim River estuary underwent major changes between 1985 and 2013, where it was possible to identify five evolutionary phases into this period. Previously, built by bar, it evolved to an estuary of coastal plain, accompanied by the progression of Torrões beach and agglutination of "barriers spits" to the continent. It is the main navigable river of the area of Itarema municipality. After the development of this work, it was possible to conclude that the forms of use and occupation in the surroundings of the Aracaratimirim River estuary had a wide growth in the last years, which reflects clearly in the estuary morphology, currently classified as an estuary of coastal plain. The morphological changes within the estuary interfere on not only the environmental conditions, but also in the economy and social conditions of the local community.
\end{abstract}

\section{INTRODUCTION}

Coastal zones can be defined as transition areas between the continent and the ocean, having significant importance in environmental, economic and sociocultural aspects (FALCÃOQUINTELA, 2008). Coastal and marine processes, intensified by the dynamics of land use and occupation, shape these areas. In dynamic balance conditions, these zones can be affected in spatial and temporal scales, suffering important transformations that might be irreversible (SUGUIO, 2003). In light of this, understanding the dynamics of this environment has fundamental importance to population planning (CHRISTOPHERSON, 2012).

The United Nations Educational, Scientific and Cultural Organization - UNESCO (1997) emphasizes that approximately $2 / 3$ of the world's population lives less than $50 \mathrm{~km}$ from the coast, harboring a little more than four billion people. In the Brazilian territory, $26 \%$ of the population (50.7 million) live in municipalities of the coastal zone, according to the Geographical Atlas of Coastal and Oceanic Zones of Brazil (2011).

Along the 8,500 km long Brazilian coastline, extending from the state of Amapá to the state of Rio Grande do Sul, there are several coastal environments, such as: bays, corals, rocky shores, deltas, beach strips, dune fields, sandy bars, swamps, cliffs, islands, coastal lagoons, lagoons, reefs, restingas and estuaries.

The study area encompasses the mouth of the Aracatimirim river estuary, located in the Torrões district, Itarema municipality, in the northwestern portion of the state of Ceará, northeastern Brazil (Figure 1).

*Arthur Amaral e Silva

arthur.amaral@ufv.br

Viçosa-MG, Brazil

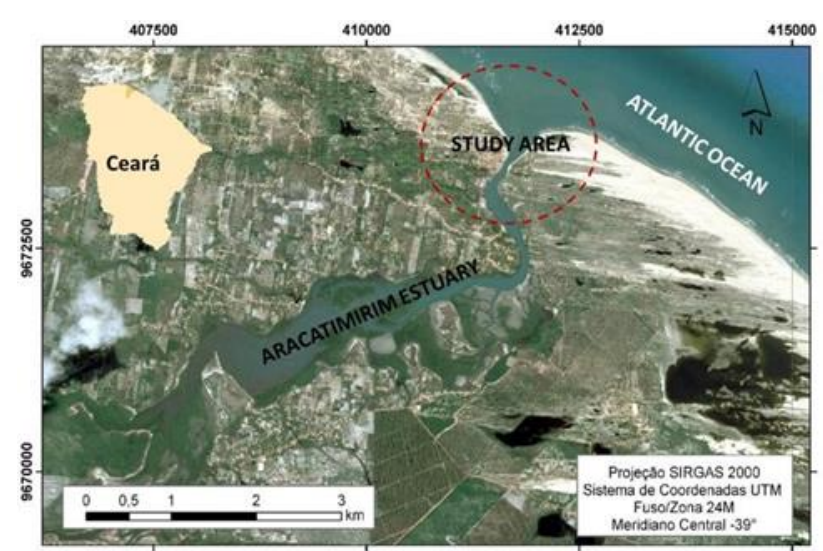

Figure 1 - Study area

Estuaries have suffered several environmental impacts resulting from the activities performed in the watershed and the coastal zone that, in most cases, becomes irreversible (FALCÃO- QUINTELA, 2008). This reflects in the total or partial displacement or closure of river mouths. A typical example is the Aracatimirim river estuary, located in the Torrões district, Itarema municipality, in the northwestern portion of the state of Ceará, Northeast Brazil.

Estuaries are geomorphological features commonly occurring on mid-latitude coastal plains found under many varied tidal, wave and climatic conditions (ROSSETI, 2008; SILVA, 2000). These are transitional areas of river and ocean waters, and are important for a scientific, environmental and economic point of view (PINHEIRO, 2003). 
The high dynamics, potential and social and environmental vulnerability make these features widely studied in their many varied locations, characteristics and classifications. (PRITCHARD, 1955; MIRANDA， 1985, 2012; KJERFVE, 1987; SCHETTINI, 2000; PINHEIRO, op. cit.; DIAS, 2005; PAULA, 2006; SOARES, 2012; FALCÃO-QUINTELA, 2008).

Based on distinct depositional forms and longitudinal variations in tidal height, Hayes (1975) proposed a geomorphological classification, in which the micro and meso tidal estuaries are associated with restingas and occasional channels of connection between the estuary or lagoon and the sea. The wide estuaries, with wide mouth and longitudinal funnel shape are characteristic of macro tidal regions.

It is also possible to classify estuaries according to the influence of sediment distribution and deposition as: dominated by rivers, when the discharge and the sedimentary river load in them surpasses the capacity of the waves and tides; by waves, where usually sandy strands or peaks that are perpendicular to the mouth occur; or tides, in this case the estuaries do not have barriers in their mouth, tending to a funnel shaped morphology, according to the influence of these factors on sediment distribution and deposition (SILVA et al., 2004).

In the characterization process of estuaries, they can be classified from the geomorphological point of view (PRITCHARD, 1955) as:

- Coastal plain: formed during the transgression of the sea in the Holocene, whose flooding process was more pronounced than the sedimentation);

- Constructed by bar: formed during marine transgression with recent sedimentation at the mouth that led to the formation of a sandy bar. Which is the classification of the estuary addressed in this study;

- Fjord: formed during the Pleistocene and generally present a rocky bottom with recent sedimentation process, mainly at the mouth;

- Remaining: estuaries formed by tectonic faults, volcanic eruptions, tremors and landslides.

The irregularities of the rainy season and the regularization of the flow associated with the oceanographic variables and wind action, as well as the inadequate dynamics of use and occupation are responsible for accelerated morphodynamic processes in the river mouths (FALCÃO-QUINTELA, 2008).

Topography and geodesy are the key application sciences in the morphological study of the mouth of estuarine systems, and the environments confronting it (beach strip, sandy bar and shoreline). (FALCÃO-QUINTELA, 2014).

Since the last decade of the twentieth century, geographical research has been influenced by new paradigms of the modern world, especially when linked to the use of geotechnologies (ALBUQUERQUE et al, 2014).

According to Rosa (2005) geotechnologies are the set of technologies for collecting, processing, analyzing and providing information with geographic reference, also known as "geoprocessing". Amongst the geotechnologies we can highlight: geographic information systems (GIS), digital cartography, remote sensing, global positioning system and topography (ROSA, 2005). software's several terms have emerged for the various specialties. The name Geographic Information System is widely used and, in many cases, is confused with geoprocessing. (ROSA, 2005). Geoprocessing is the broadest concept and represents any kind of georeferenced data processing, while a GIS processes graphical and non-graphical (alphanumeric) data with an emphasis on spatial analysis and surface modeling. (BURROUGH, 1987).

Georeferencing techniques have several applicability, such as municipal and rural registers, uses during sanitation installation processes and electrical distribution networks, application in social work monitoring (education, health, government programs and etc.), and performing environmental monitoring.

The main goal of this study is applying the use of geotechnology to analyze the morphological changes in the Aracatimirim River's mouth (CE) contributing with useful information to the local community, monitoring and environmental management of tropical coastal estuaries.

In a more specific manner, the project aimed to characterize the study area considering climatology, geology, geomorphology and hydrology. Applying georeferencing and geoprocessing technics for spatial and temporal analysis of the estuary's mouth morphology, correlating with data collected in loco; quantifying the dynamics of use and occupation around the river mouth; collaborating with information useful in the morphological study, observation and management of estuaries.

\section{METHODOLOGY}

To obtain data and achieve results from the established objective, the methodology was divided into three stages: recognition of the study area; field activity and data processing and integration

\subsection{Recognition of the study area}

Bibliographic surveys were conducted in the local, national and international context, to construct the theoretical framework. Multitemporal satellite images were obtained free of charge from the Google Earth Pro ${ }^{\circledR}$ software in order to obtain preliminary information of the area to be studied. Dates, resolutions, and image types are detailed in Table 1.

\begin{tabular}{ccc}
\hline Image Date & Resolution & Image type \\
\hline $05 / 01 / 04$ & $4800 \times 2843$ & Digital globe \\
$08 / 09 / 04$ & $4801 \times 2843$ & Digital globe \\
$28 / 11 / 10$ & $4802 \times 2843$ & Digital globe \\
$16 / 11 / 12$ & $4803 \times 2843$ & Digital globe \\
$01 / 04 / 13$ & $4804 \times 2843$ & Digital globe \\
$21 / 06 / 14$ & $4805 \times 2843$ & CNES/Airbus \\
$25 / 06 / 16$ & $4806 \times 2843$ & CNES/Airbus \\
\hline
\end{tabular}

Table 1 - Satellite images descriptions.

From the elaboration of a provisional location map, Global Positioning System (GPS) receiver and camera, it was possible to obtain updated information to delimitate the study area and determine the monitoring points in the recognition field.

\subsection{Field activity}

Field data (water and soil samples, coordinates, were collected on March 17 and 18, 2018, in the low tide tidal wave, during the rainy season, in order to obtain more information on the geomorphological and sedimentological features of the estuary mouth.

With the evolution of geoprocessing technology and graphic 
Regarding the morphological aspects, the sea line survey, the low line, the beach profile and control points were defined. For georeferencing the satellite images, the base of the geodetic equipment was installed in a strategic location and configured in Projection SIRGAS 2000, coordinates UTM and Zone / Zone 24M. The base was worked at the Post Processed Point (PPP), whose screening time was 4 hours and 45 minutes.

With aid of a Rover it was also possible to build 10 beach profiles perpendicular to the pre-sea line towards the low-sea line (Table 2). Thus, it was possible to determine the length of the beach strip, elevation (maximum and minimum), level difference, slope, grid azimuth, generate contours and determine the sediments volume.

\begin{tabular}{|c|c|c|c|c|c|}
\hline \multicolumn{3}{|c|}{ North Shore } & \multicolumn{3}{|c|}{ East Shore } \\
\hline Profile & $\begin{array}{c}\text { North } \\
\text { (m) }\end{array}$ & $\begin{array}{l}\text { East } \\
(\mathrm{m})\end{array}$ & Profile & $\begin{array}{c}\text { North } \\
\text { (m) }\end{array}$ & $\begin{array}{l}\text { East } \\
\text { (m) }\end{array}$ \\
\hline 1 & $\begin{array}{c}967343 \\
9,775\end{array}$ & $\begin{array}{c}411610 \\
, 147\end{array}$ & 6 & $\begin{array}{c}967340 \\
3,004\end{array}$ & $\begin{array}{c}411720 \\
, 218\end{array}$ \\
\hline 2 & $\begin{array}{c}967356 \\
8,151\end{array}$ & $\begin{array}{c}411650 \\
, 326\end{array}$ & 7 & $\begin{array}{c}967348 \\
9,224\end{array}$ & $\begin{array}{c}411829 \\
, 158\end{array}$ \\
\hline 3 & $\begin{array}{c}967365 \\
5,410\end{array}$ & $\begin{array}{c}411656 \\
, 493\end{array}$ & 8 & $\begin{array}{c}967355 \\
1,752\end{array}$ & $\begin{array}{c}411894 \\
, 990\end{array}$ \\
\hline 4 & $\begin{array}{c}967375 \\
3,230\end{array}$ & $\begin{array}{c}411592 \\
, 107\end{array}$ & 9 & $\begin{array}{c}967371 \\
2,823\end{array}$ & $\begin{array}{c}412047 \\
, 762\end{array}$ \\
\hline 5 & $\begin{array}{c}967406 \\
9,981\end{array}$ & $\begin{array}{c}411361 \\
, 181\end{array}$ & 10 & $\begin{array}{c}967373 \\
0,247\end{array}$ & $\begin{array}{c}412528 \\
, 024\end{array}$ \\
\hline
\end{tabular}

Table 2 - UTM coordinates of topographic profiles.

To measure tidal amplitude, a millimeter-accurate topographic grade rod was installed on the west bank of the Aracatimirim River located at the coordinates UTM $9673432.9020 \mathrm{mN} / 411634.0860 \mathrm{mE}$. The readings were taken every 10 minutes, totaling 56 samples.

The topographic rod was installed at ebb tide and removed at flood tide. It was possible to know the estuarine area tide height. Data were tabulated to make graphs, to correct the topographic profiles in relation to the water level (W.L.) and to verify the tide delay.

\subsection{Office Stage}

For data collection using GNSS receivers, the georeferencing method of the National Institute of Colonization and Agrarian Reform - INCRA (2009) was adopted.

From the Information reports it was possible to process the base data of the geodetic equipment through the Trimble software to determine the UTM coordinates in a precision way, using SIRGAS 2000 projection, 24M zone and central meridian $-39^{\circ}$. It was also possible to obtain the ellipsoidal altitude $(\mathrm{h}=-10.134 \mathrm{~m})$

From the MAPGEO ONLINE Program, available from the Brazilian Institute of Geography and Statistics (IBGE), it was possible to determine the geoidal undulation $(\mathrm{N}=-12.43 \mathrm{~m})$

To calculate the orthometric altitude $(\mathrm{H})$ it was necessary to obtain the ellipsoidal altitude (h) and geoidal ripple (N) using Equation 1:

$$
\mathrm{H}=\mathrm{h}-\mathrm{N}
$$

In which: $\mathrm{H}=$ orthometric altitude;

$\mathrm{h}=$ ellipsoidal altitude;

$\mathrm{N}=$ geoidal ripple

Subsequently, the rover data were processed from the UTM base coordinates corrected in the Trimble software, totaling 820 points (north, east and ellipsoidal altitude) collected.

Topograph software was used to determine the points orthometric altitudes. ArcMap 10.4.1 was used for map confection and data collection.

The slope, grid azimuth, level difference, horizontal distance, area and volume values were calculated using the Topograph and Autocad softwares.

Georeferencing techniques were performed on satellite images from five control points established in the field with aid of a geodetic receiver (Table 3).

\begin{tabular}{ccc}
\hline Control Points & North (m) & East (m) \\
\hline 1 & 9673728,00 & 412114,00 \\
2 & 9673422,00 & 411256,00 \\
3 & 9673439,88 & 411609,70 \\
4 & 9673451,00 & 411969,00 \\
5 & 9673889,00 & 411322,00 \\
\hline
\end{tabular}

Table 3 - UTM coordinates of control points for georeferencing satellite images.

The georeferencing graphical image errors of dated from November / 2010 and June / 2016 were $0.239 \mathrm{~m}$ and $0.422 \mathrm{~m}$, respectively (Figures 1 and 2). The scale adopted to apply geoprocessing techniques was $1 /$ 6,000 . Thus, using $0.2 \mathrm{~mm}$ accuracy, the graphical error is within the allowed range, i.e. $<1.2 \mathrm{~m}$. The georeferenced images made it possible to obtain area, perimeter and coordinate data. 


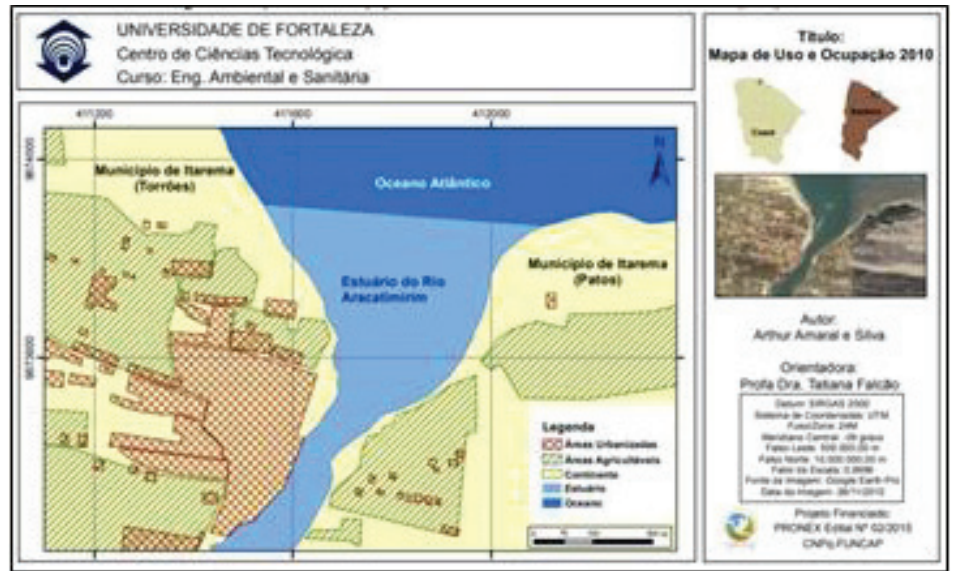

Figure 2 - Land use map of 2010

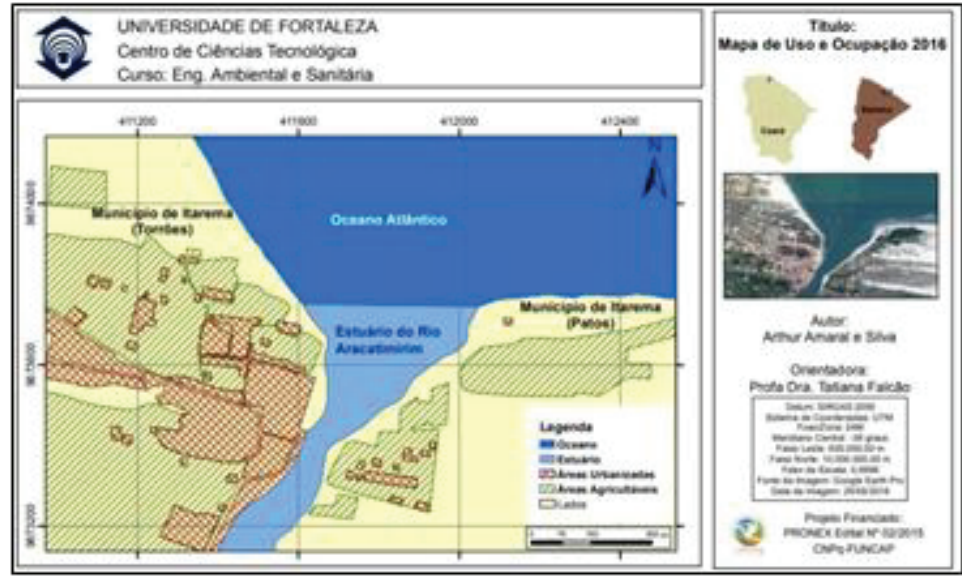

Figure 3 - Land use map of 2016

\section{RESULTS AND DISCUSSION}

The study area is located in the Litoral Watershed, in the Northwest portion of Ceará State, Northeast Brazil. The drainage area of the Aracatimirim River corresponds to $1,565 \mathrm{~km}^{2}$ of the total basin $\left(8,619 \mathrm{~km}^{2}\right)$ according to the Water Resources Management Company (COGERH).

The Litoral Hydrographic Basin presents a dendritic drainage, that is, there are several tributaries with different directions in the upper and middle course of the river that unite forming a main river in the middle to lower course. Since basin rivers flow into the Atlantic Ocean, they are classified as exorheic.

According to Paula (2006) the effect of waves and tides within an estuary is related to shoreline morphology, climatic aspects, bottom morphology and channel width. Such effect is responsible for the variation of tidal height and the intensity of the currents, causing significant changes in the river mouth morphology.

From a topographic ruler installed at the coordinates UTM $9673432.9020 \mathrm{mN} / 411634.0860 \mathrm{mE}$ with distances of $610.00 \mathrm{~m}$ from the mouth and $129 \mathrm{~km}$ from the Port of Pecém, it was possible to verify that on March $17^{\text {th }}, 2018$ the tide had a delay of 1 hour and 39 minutes when compared to Porto do Pecém tide table. The next day, $18^{\text {th }}$, had a tide delay of 1 hour and 36 minutes.

A tide variation corresponding to $2.025 \mathrm{~m}$ was recorded, with minimum values of $0.680 \mathrm{~m}$ and maximum of $2.705 \mathrm{~m}$ on the first fieldwork day. In the monitoring period, from 9:20 to 12:30, it was found that the tide took $3 \mathrm{~h} 10$ to reach low tide. From $12 \mathrm{~h} 30$ to $14 \mathrm{~h} 50$ a rise in the water mass of $2.025 \mathrm{~m}$ was recorded in a $2 \mathrm{~h} 20$ interval. It was noticed that the water takes longer to reach the low tide upholstery. Such fact happens due to the increase of the river flow and the bottom morphology of the mouth. Based on the data obtained and analyzed from tidal ranges, the coast of the State of Ceará is classified as meso-tide (2-4m) (SILVA et al. 2004).

From the images available on Google Earth Pro software in a 12-year temporal scale (2004-2016) it was possible to ratify Mesquita et al (2014) and observe significant changes in Aracatimirim river's mouth estuary morphology and the increased urbanized area around it.

According to the classification proposed by Pritchard (1952b, apud MIRANDA, CASTRO AND KJERFVE, 2002), the river estuary mouth geomorphology is sandy spit type in images dated from January and September of 2004. At the 8-month time scale (January 2004 to September 2004), the sandy bar reduced $59.7 \mathrm{~m}$ in the direction of $295.82^{\circ}$ (grid azimuth), a loss of approximately $7.5 \mathrm{~m}$ in length per month

The widths are quite diverse in the direction of $51.20^{\circ}$ (grid azimuth), with values ranging from $38.76 \mathrm{~m}$ to $260.83 \mathrm{~m}$ and average of $147.98 \mathrm{~m}$ in January/2004. In September/2004, it was also possible to observe a variation in the dimensions of the sandy spit, with values from $30.51 \mathrm{~m}$ to $291.25 \mathrm{~m}$ in the aforementioned direction and an average of 158.96 $\mathrm{m}$. Thus, we can say that in these 08 months the estuary lost in extension, but gained in width. The area of the sandy spit decreased from $34,226.00 \mathrm{~m}^{2}$ (January / 2004) to $32,409.00 \mathrm{~m}^{2}$ (September / 2004).

From the image dated November 2010, it was possible to observe a change in the river mouth geomorphology. The sandy bar disappeared from the east bank of the Aracatimirim River and increased the river's communication with the Atlantic Ocean. Thus, the geomorphology of the mouth of the river estuary was classified as coastal plain.

The effects of river mouth migration or partial or total closure are due to various coastal and oceanic processes, seasonality (drought and rainy season), and more often, anthropic interventions.

The disordered population growth, within medium and large cities, added to the lack of awareness and planning during the process of land use and occupation, generating geomorphological changes, since such growth does not obey the biophysical conditioning of the original implementation place. (PINHEIRO, 2003). From the image vectorization of the multitemporal images, it was possible to quantify the occupied areas around the mouth of the Aracatimirim River.

Thus, the analysis of the geomorphological part within the study area allowed obtaining results that can describe the changes caused during the growth process of the levels of land use and occupation around the Aracatimirim River estuary, as well as show the impacts caused by this growth within the estuary.

In 2010 (Figure 2), on the west bank of the river, the area occupied by buildings, developments and housing corresponded to $3,049.45 \mathrm{~m}^{2}$. As for the arable areas, these corresponded to $126,041.09 \mathrm{~m}^{2}$, and the unoccupied continental area covered $389,092.12 \mathrm{~m}^{2}$. Analyzing the continental zone, the forms of use and occupation and the arable areas, as a percentage, we have the values correspond to $75.09 \%, 0.59 \%$ and $24.32 \%$, respectively.

On the eastern bank of the river, the unoccupied continental zone corresponded to $180617.33 \mathrm{~m}^{2}$, the forms of use and occupation covered $139.165 .8848 \mathrm{~m}^{2}$ and the arable area covered $271.117 .29 \mathrm{~m}^{2}$ of the total area. Statistically, it was possible to state that the areas previously mentioned correspond to $30.57 \%, 23.55 \%$ and $45.88 \%$ respectively. 
In 2016 (Figure 3), on the west bank of the Aracatimirim River, the clear continental zone covered $209,877.25 \mathrm{~m}^{2}$, the area occupied by buildings, developments and housing corresponded to $151,289.00 \mathrm{~m}^{2}$ and the agricultural area was $327,350.51 \mathrm{~m}^{2}$, which corresponds to $30.49 \%, 21.97 \%$ and $47.54 \%$, respectively. On the east bank of the river, the area related to the unoccupied continental zone was $394,700.84 \mathrm{~m}^{2}$, with respect to land use and occupation, which covered $6,991.11 \mathrm{~m}^{2}$ of the total area, and the arable zone, corresponded to $107,317.75 \mathrm{~m}^{2}$. Statistically, it was concluded that the previously mentioned areas correspond to $77.54 \%, 1.37 \%$ and $21.09 \%$, respectively.

As for the Aracatimirim river estuary, in 2010 it had an area of $139,496.25 \mathrm{~m}^{2}$, while in 2016 it had an area of $119,615.88 \mathrm{~m}^{2}$. Thus, it was possible to verify that within this six-year interval the estuary area had a decrease of $14.25 \%$, while the use and occupation areas and the agricultural zones had a growth of $11.30 \%$ and $183.80 \%$, respectively. Thus, it can be stated that the increase of anthropic action around the estuarine area has caused changes within the estuary, such as the siltation of the river, causing a reduction in its size.

Monitoring the shoreline is considered a major problem when it comes to studying small and large-scale evolution because of its dynamics and instability over time (day, months, years, decades and centuries). There is a constant need to obtain updated data on shoreline behavior. Thus, we will have subsidies for good coastal planning, especially in densely occupied and urbanized areas (FALCÃO-QUINTELA, 2014).

According to DHN (1966), a shoreline is understood to be an interface area of the continent and the ocean, i.e., the limit of the effective action of the sea. It is considered one of the geomorphological features of the most dynamic coastal zone on the planet (ROCHA et al., 2008).

To analyze the evolution of shorelines in recent years, georeferencing and geoprocessing techniques were applied to satellite images dating from 2010 and 2016 to draw a control line, and then to be able to calculate the setback rates. In addition, a geodetic receiver was used to obtain updated area information.

In general, monitoring the shoreline as well as the tidal (low tide) and low tide (low tide) lines is of fundamental importance for proper coastal zone planning and management. Moreover, the multitemporal data of the mentioned lines serve to trace the evolution from its displacement, as well as to indicate erosion or deposition sectors. It was possible to obtain information regarding the beach strip width, level difference and slope.

From the data obtained from the pre and low sea lines, around the mouth of the river, it was possible to trace the evolution of the morphology of the mouth of the Aracatimirim River. Updated data obtained from the geodetic receiver indicated that the mouth continues to be classified as coastal plain.

Beach strips make up the frontal environment of many coastal systems, such as at the mouth of rivers. "The topographic profile is one of the crucial tools for the planning and management of coastal environments, so it is important to know the best method and equipment for obtaining beach range altimetric data." (FALCÃO-QUINTELA, 2014).

Topographic profiling is understood to be a graphical representation of a section of the terrain. From the graph, it is possible to obtain data on width (m), level difference (m), dimension $(\mathrm{m})$, area $\left(\mathrm{m}^{2}\right)$, volume $\left(\mathrm{m}^{3}\right)$, slope in percent $(\%)$ and degrees $\left({ }^{\circ}\right)$
Regarding the morphological analysis of the profiles, it was possible to obtain the values of area $\left(\mathrm{m}^{2}\right)$, perimeter $(\mathrm{m})$, horizontal distance $(\mathrm{m})$ and slope (\%). The profiles were numbered 1 to 10 , where numbering profiles 1 to 5 were on the west bank of the estuary. Profiles numbered 6 to 10 are located on the eastern bank of the estuary (Table 4).

\begin{tabular}{|c|c|c|c|c|}
\hline Profile & \multicolumn{2}{|c|}{ Grid Azimuth } & $\begin{array}{c}\text { Area } \\
\left(\mathrm{m}^{2}\right)\end{array}$ & $\begin{array}{l}\text { Perimeter } \\
\text { (m) }\end{array}$ \\
\hline 1 & \multicolumn{2}{|c|}{$108^{\circ} 39^{\prime} 33^{\prime \prime}$} & 454,921 & 178,383 \\
\hline 2 & \multicolumn{2}{|c|}{$111^{\circ} 49^{\prime} 28^{\prime \prime}$} & 1215,865 & 510,905 \\
\hline 3 & \multicolumn{2}{|c|}{$91^{\circ} 53^{\prime} 31^{\prime \prime}$} & 2798,557 & 1019,788 \\
\hline 4 & \multicolumn{2}{|c|}{$82^{\circ} 17^{\prime} 44^{\prime \prime}$} & 8218,811 & 2908,400 \\
\hline 5 & \multicolumn{2}{|c|}{$59^{\circ} 02^{\prime} 48^{\prime \prime}$} & 1207,032 & 386,061 \\
\hline 6 & \multicolumn{2}{|c|}{$286^{\circ} 33^{\prime} 58^{\prime \prime}$} & 659,609 & 307,828 \\
\hline 7 & \multicolumn{2}{|c|}{$316^{\circ} 40^{\prime} 24^{\prime \prime}$} & 798,578 & 330,486 \\
\hline 8 & \multicolumn{2}{|c|}{$300^{\circ} 37^{\prime} 53^{\prime \prime}$} & 539,226 & 269,525 \\
\hline 9 & \multicolumn{2}{|c|}{$287^{\circ} 12^{\prime} 14^{\prime \prime}$} & 1048,903 & 455,454 \\
\hline 10 & \multicolumn{2}{|c|}{$352^{\circ} 37^{\prime} 22^{\prime \prime}$} & 5398,144 & 1062,961 \\
\hline Profile & Slope (\%) & $\begin{array}{c}\text { Maximum } \\
\text { elevation } \\
\text { (m) }\end{array}$ & $\begin{array}{c}\text { Minimum } \\
\text { Elevation } \\
\text { (m) }\end{array}$ & $\begin{array}{l}\text { Horizontal } \\
\text { distance } \\
\text { (m) }\end{array}$ \\
\hline 1 & $-13,08$ & 2,728 & 0,000 & 20,844 \\
\hline 2 & $-3,98$ & 2,438 & 0,000 & 62,636 \\
\hline 3 & $-2,20$ & 2,769 & 0,000 & 126,070 \\
\hline 4 & $-0,78$ & 2,837 & 0,000 & 362,125 \\
\hline 5 & $-6,95$ & 3,239 & 0,000 & 46,581 \\
\hline 6 & $-5,91$ & 2,208 & 0,000 & 37,342 \\
\hline 7 & $-6,23$ & 2,494 & 0,000 & 40,024 \\
\hline 8 & $-6,33$ & 2,066 & 0,000 & 32,625 \\
\hline 9 & $-4,22$ & 2,351 & 0,000 & 55,769 \\
\hline 10 & $-3,99$ & 2,726 & 0,000 & 130,222 \\
\hline
\end{tabular}

Table 4: Beach Profile Features.

After the development of this work, it was possible to conclude that the forms of use and occupation around the Aracaratimirim river estuary had a wide growth in the last 10 years, which clearly reflects the morphology of its mouth. From the performed analyzes, it was found that the estuary in question, which was previously built by bar, is currently classified as a coastal plain estuary. Such changes are related to the sedimentary characteristics of the site, directly influence the ebb, and flow process in the estuary.

Another factor, such as the irregularity of the rainy season during the period from 2010 to 2016, where a long period of drought came to be, especially in 2012, also has a direct influence on the geomorphological changes of the study area. Because the drought period causes a decrease in freshwater flow, allowing coastal sea currents to carry sedimentary material into the estuary, as the estuarine current is not strong enough to block the marine currents, causing the action of the coastal drift is more intense and has greater impacts on the morphology of the mouth of the Aracatimirim estuary.

These changes have a direct impact on the local population, which has a large part of their income linked to fishing, causing a direct dependence on the navigation conditions of the Aracatimirim river. Thus, morphological changes within the estuary interfere not only with 
environmental conditions, but also with the economy and with social conditions of the local community of Torrões municipality.

Given the importance of continuing field studies, new field activities for up-to-date data collection, as well as other experiments in the field of studies that were not applied to the work in question, have been indicated.

\section{CONCLUSION}

After the development of this work, it was possible to conclude that the forms of use and occupation around the Aracaratimirim estuary had a growth in the last 10 years, which clearly reflects in the estuary mouth's morphology. From performed analysis, found that the estuary, that before was built by bar, it is currently classified as a lowland coastal estuary. Such changes are related to the sedimentary characteristics of the site, directly influence the ebb, and flow process in the estuary.

Another factor, such as the irregularity of the rainy season during the period of 2010 to 2016 , where a long period of drought came to be faced, mainly in 2012, also has a direct influence on the geomorphological changes in the study area. The drought period decreases the flow of fresh water, allowing that the coastal currents carry out the loading of the sedimentary material into the estuary, as the estuarine current is not strong enough to spread marine currents, making the action of coastal drift more intensity and cause greater impacts on the mouth of the estuary Aracatimirim River.

These changes have a direct impact on the local population, which has great part of their income linked to fishing, making them directly dependent on navigation conditions of the Aracatimirim River. Thus, the morphological changes within the estuary interfere in not only environmental conditions, but also in the economy and social conditions of the local community in the municipality of Torrões.

\section{REFERENCES}

Falcão-Quintela, Tatiana Oliveira Falcão. A dinâmica ambiental do Estuário do Rio Curu - CE: subsídios para o monitoramento e gerenciamento da Área de Proteção Ambiental. 2008. 140 p. Dissertação (Mestrado Acadêmico em Geografia) - Centro de Ciências Tecnológicas, Universidade Estadual do Ceará, Fortaleza, 2008.

Falcão-quintela, Tatiana Oliveira; Morais, Jader Onofre; Pinheiro, Lidriana de Souza. Morphodynamics of the Curu Estuary Inlet Brazil. Journal of Coastal Research, v. 64, p. 805808, 2011.

Pinheiro, Lidriana de Souza. Riscos e gestão ambiental no Estuário do Rio Malcozinhado, Cascavel-CE. 2003. 230f. Tese (Pós-Graduação em Oceanografia) - Universidade Federal de Pernambuco, Recife, 2003.

Silva, Arthur Amaral e. Geotecnologia aplicada à análise morfológica da desembocadura do estuário do rio Aracatimirim (Torrões - CE). 2018. Trabalho de Conclusão de Curso - Universidade de Fortaleza, Fortaleza, 2018.

DALRYMPLE, R.W. Tidal depositional systems. In: WALKER, R. G.; JAMES, N. P. (Eds.). Facies Models:

Response to Sea Level Change. Canada: Geological Association of Canada, St. John's, 1992.

DAVIES, J. L. Geographical variation in coastal development. New York: Hafner, 1973.
FAIRBRIDGE, R. W. The estuary: its definition and geodynamic cycle. In: OLAUSSON, E.; CATO, I. (Eds.). Chemistry and Geochemistry of Estuaries. New York: Wiley, 1980.

KJERFVE, B. Estuarine Geomorphology and Physical Oceanography. In: DAY Jr.; HALL, C.H.A.S.; KEMP, W.M.; YÁNEZ-ARANCIBA, A. (Eds.). Estuarine Ecology. New York: Wiley, p. 47-78, 1987.

MUEHE, Dieter. Geomorfogia Costeira, In: GUERRA, Antonio José Texeira; CUNHA, Sandra Baptista da (Org). Geomorfologia: uma atualização de bases e conceitos. Rio de Janeiro: Bertrand Brasil, 1994.

PRITCHARD, D. W. Estuarine circulation patterns. Proceeding of the American Society of Civil Engineering, v. 81, n. 717, 1955.

\section{ACKNOWLEDGMENT}

To the project geodiversities, interactions and social and environmental impacts in the beach-platform system of the west coast of the state of Ceará, with funding from the Cearense Foundation to Support Scientific and Technological Development - FUNCAP. 